鼓室形成術後の語音聴力検査

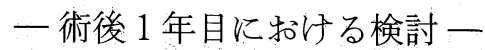

相原 康孝・小林 謙・佐久間文子
石田
祐子 - 浜田 慎二 - 上村 敏夫
神尾 友和

\title{
Speech Audiometry One Year after Tympanoplasty
}

\author{
Yasutaka Aihara, Yuzuru Kobayashi, Ayako Sakuma, \\ Yuko Ishida, Shinji Hamada, Toshio Kamimura \\ and Tomokazu Kamio
}

(Kamio Memorial Hospital)

Speech reception thresholds were analyzed in 71 patients with chronic otitis media one month before and after and one year after typmpanoplasty. Bone conduction thresholds of all the subjects were within the normal range.

In $19 \%$ of the subjects improvement in the reception threshold was observed one month and one year after the operation. The air conduction threshold was also markedly improved after both one month and one year.

In $12 \%$ of the subjects the speech reception threshold improved after on month, but one year later the threshold had reverted to the pre-operation level. The air conduction threshold was improved after one month, but after one year it was in the low frequency zone.

In $17 \%$ of the subjects the speech reception threshold remained the same after one month but had improved by one year after surgery. The air conduction threshold also showed no significant change after one month but was improved after one year.

In $33 \%$ of the subjects no significant change was noted in the speech reception threshold either one month or one year after the operation. The air conduction threshold the same.

The results suggest that it is too early to judge the improvement of the speech reception threshold one month after tympanoplasty. Therefore, speech audiometry should be carried out one year after tympanoplasty.

In several cases the changes in the air conduction threshold and those in the speech reception threshold were different. Accordingly, pure tone audiometry and speech audiometry are considered necessary to evaluate hearing after tympanoplasty.

Key words: tympanoplasty, speech audiometry, speech reception threshold 


\section{はじめに}

鼓室形成術後の聴力変化の判定には，主に純 音聴力検査をその指標として用いる11)。しい， 我々は鼓室形成術の術前および術後 1 力月目の 純音聴力と語音聴力検查の結果を比較検討し， 両者の変化が必ずしも一致せず，聴力変化の判 定には両者を合わせて行らことが望ましいこと を報告した ${ }^{2)}$. 一方，判定の時期については， 術後 6 力月3) あるいは 1 年目4)5) など様々であ るが，これらはいずれも純音聴力検査によるも のであり，語音聴力による検討はなされていな い.今回，鼓室形成術術前，術後 1 力月目括よ び 1 年目の純音聴力および語音聴力検査の結果 とを比較し, 聴力变化の判定の時期について検 討した。

\section{対象と方法}

神尾記念病院にて鼓室形成術を施行した症例 のうち術前後ともに骨導聴力レベルの低下を認 めなかった71例78耳(男37例41耳, 女34例37耳, 平均年齢は35.3歳)を対象とした，純音聴力検 査はリオン社製 AA61B で行い, 語音聴力検査 は67S式ことば表を用い,語音聴取閾値 (speech reception threshold：SRT)を指標とした。検 査は術前, 術後 1 力月, 術後 1 年目に行い, 純 音聴力と語音聴力を比較検討した。

\section{結 果}

語音聴取閾値が術後 $10 \mathrm{~dB}$ 以上改善した症 例は 1 カ月目では 25 耳 $(32 \%) ， 1$ 年目では $28 耳$ (36\%)であった。変化が $10 \mathrm{~dB}$ 未満であった 症例は術後 1 力月目では 46 耳 $(59 \%), 1$ 年目で は38耳(49\%)であった. $10 \mathrm{~dB}$ 以上悪化した症 例は術後 1 カ月目では 7 耳 $(9 \%) ， 1$ 年目では 12耳 (15\%)であった。

全症例の語音聴取閾值の変化の推移を表 1 に 示した。術後 1 カ月目に語音聴取閾値が 10 $\mathrm{dB}$ 以上改善した 25 耳のらち術後 1 年目にも改 善していた症例は 15 耳, 変化が $10 \mathrm{~dB}$ 未満と なった症例は 9 耳, $10 \mathrm{~dB}$ 以上悪化した症例は 1 耳であった. 術後 1 カ月目に語音聴取閾值の 変化が $10 \mathrm{~dB}$ 未満であった46耳のうち，術後
1 年目には $10 \mathrm{~dB}$ 以上改善した症例は 13 耳, 1 年目も変化が $10 \mathrm{~dB}$ 未満であった症例は 26 耳， $10 \mathrm{~dB}$ 以上悪化した症例は 7 耳であった。 術後 1 力月目に語音聴取閾値が $10 \mathrm{~dB}$ 以上悪 化した 7 耳のうち 1 年目に変化が $10 \mathrm{~dB}$ 未満 となった症例は 3 耳, 1 力月目と同様に悪化し ていた症例は 4 耳であった。 1 カ月目に語音聴 取閾值が $10 \mathrm{~dB}$ 以上悪化した症例で 1 年目に 10 $\mathrm{dB}$ 以上改善した症例は認められなかった。

術後 1 力月目， 1 年目ともに語音聴取間值が 改善した15耳，1 カ月目には語音聴取閾値が改 善したものの 1 年目には不変となった 9 耳， 1 カ月目には語音聴取閾値が不変であったが， 1 年目には改善した 13 耳, および 1 カ月， 1 年目 ともに語音聴取閾值が不変であった 26 耳それぞ れの術前, 術後 1 力月目, 1 年目の周波数別気 導聴力レベルの平均值を図 $1 \sim 4$ に示した.

1 力月， 1 年目ともに語音聴取閾值が改善し ていた症例の低および中音域気導聴力レベルは 術後 1 力月目に改善し術前と有意な差を認めた. 高音域の気導聴力レベルに変化は認められなか ったそその後はすべての周波数で気導聴力レべ ルに変化はなく， 1 年目の気導聴力レベルは 1 カ月目と変化が認められなかった.

表 1 術後の語音聴取閾値の変化

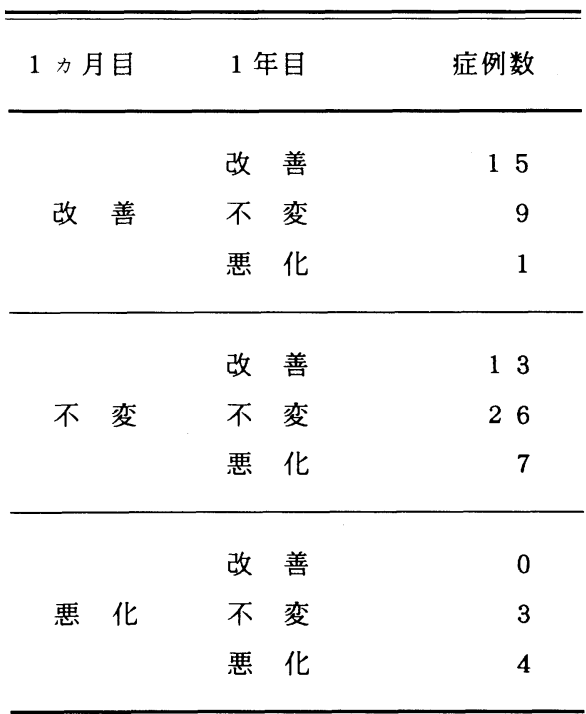


1 力月目に語音聴取閾值が $10 \mathrm{~dB}$ 以上改善 したものの， 1 年後には変化が $10 \mathrm{~dB}$ 未満と なった症例の気導聴力レベルは術後 1 カ月目で は $8 \mathrm{kHz}$ を除く周波数で改善し, 術前と有意 な差を認めた。しかし，その後，聴力レベルが 悪化し, 術後 1 年目で術前に比べ $1 \mathrm{kHz}$ から $4 \mathrm{kHz}$ の気導聴力レベルでのみ改善を認めた.

1 カ月目には語音聴取閾值の変化は $10 \mathrm{~dB}$ 未

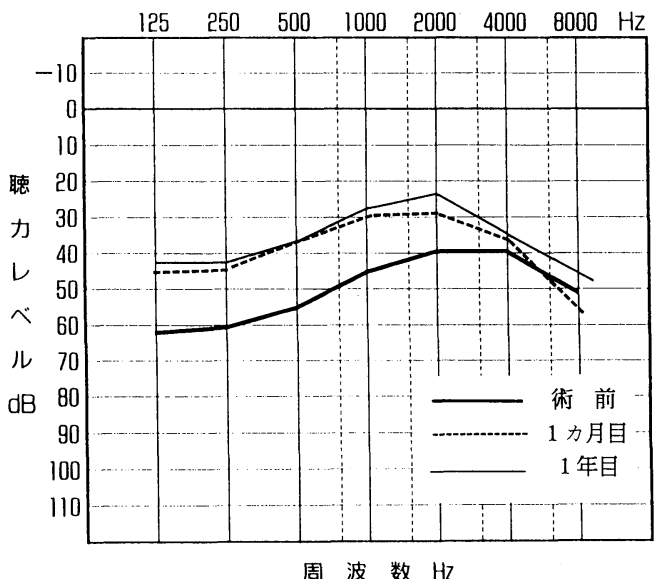

図 1 語音聴取閾値が 1 力月目, 1 年目ともに改 善を示した症例のオージオグラム

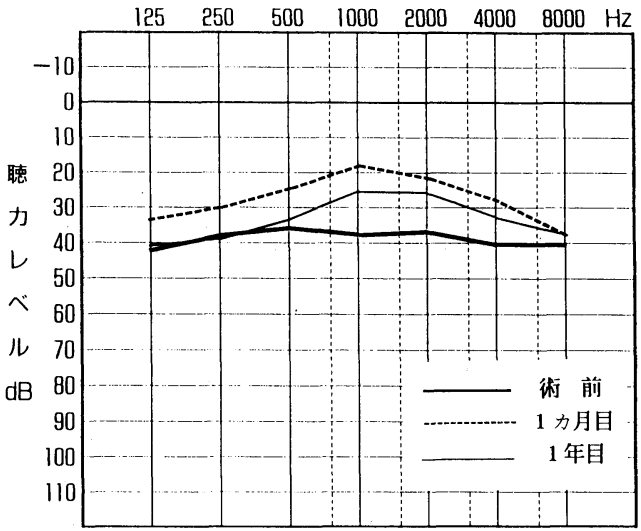

周 波 数 $\mathrm{Hz}$

図 2 語音聴取閾值が 1 力月目に改善し, 1 年目 には術前と同じ程度に戻った症例のオージ オグラム
満であったが， 1 年目には $10 \mathrm{~dB}$ 以上改善した 症例では, 気導聴力レベルは 1 カ月目では低音 域で有意に改善しているが，中音域や高音域で は改善がみられなかった。しかし，1年目には 全ての周波数で聴力レベルが改善し，術前と有 意差を認めた。

1 カ月目拉よび 1 年目ともに語音聴取閾值の 変化が $10 \mathrm{~dB}$ 未満であった症例では気導聴力

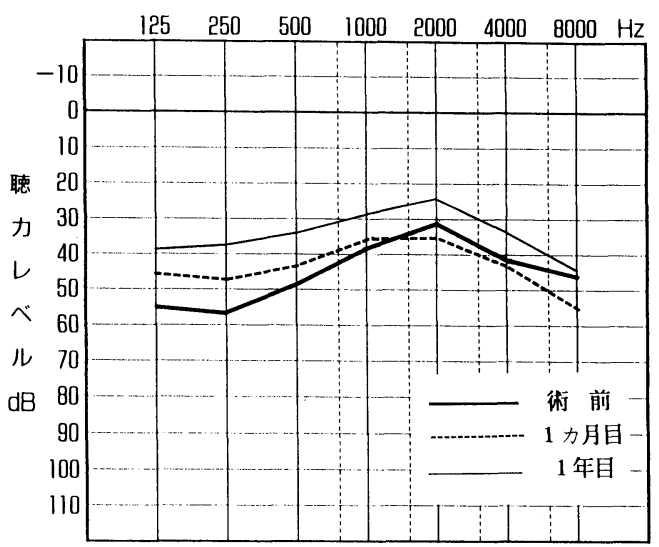

周 波 数 $\mathrm{Hz}$

図 3 語音聴取閾値が 1 カ月目には改善せず, 1 年目に改善を示した症例のオージオグラム

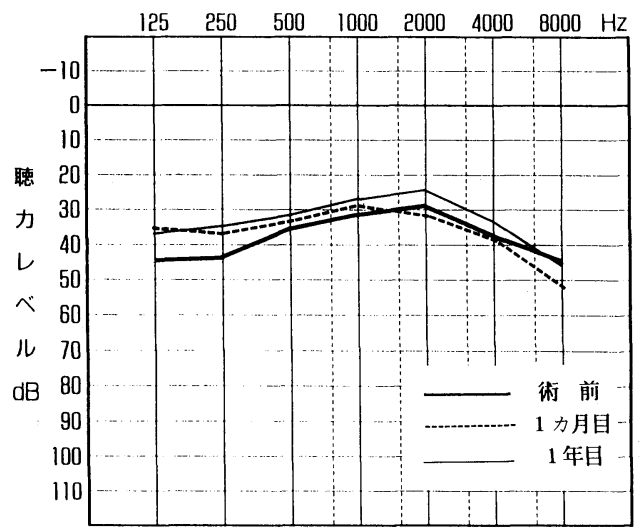

周 波 数 $\mathrm{Hz}$

図 4 語音聴取閾值が 1 カ月目, 1 年目ともに変 わらなかった症例のオージオグラム 
レベルは 1 カ月目では低音域では有意に改善し ていたが，他の周波数では改善は見られず，8 $\mathrm{kHz}$ では気導聴力レベルの悪化を認めた。一 方 1 年目には低音域から中音域では 1 力月目々 変化はなく，高音域では 1 力月目と比べると有 意に改善していたが, 術前と比較すると有意差 は認められなかった。

\section{考察}

全78耳のうち術後 1 力月:目と術後 1 年目の語 音聴取閾値の変化が一致していた症例は 45 耳 約 $60 \%$ であった。また語音聴取閾值の術後の推 移をみると, 術後 1 力月目ですでに改善を認め た症例, 術後 1 力月目では語音聴取閾值は改善 せず，1 年目に改善を認めた症例などさまざま であり, 術後聴力変化の判定は術後 1 力月目な どといった術後早期ではなく, 術後 1 年目など 長期を経過してから行う必要があると考兄られ る. 純音聴力の検討でも術後 3 力月に主に聴力. 変化が認められ, 術後 1 年で匡ぼ安定するとさ れ ${ }^{6)}$, 今回の語音聴力からの検討と同じ結果で あった。

語音聴力の推移と純音聴力の推移を比較する と, 術後 1 力月目から改善を認めた症例では, 術後 1 力月目に低中音域の純音聴力レベルが改 善し, 術後 1 年目も同様であった。一方, 術後 1 力月目に語音聴取閾值は改善せず, 術後 1 年 目になり改善した症例でも, 術後 1 力月目には 純音聴力レベルの改善を認めた。また, 語音聴 取閾值が術後 1 力月目には改善したが術後 1 年 目は術前と比較し不変となった症例では, 術後 1 カ月目に改善した純音聴力レベルが術後 1 年 目には悪化するものの中音域の聴力レベルは依 然術前と比較し有意に改善していた。このよう に語音聴力検查の結果と純音聴力検查の結果と は必ずしも一致しない場合があり，注意を要す る。

前回我々は語音聴力には中音域のみではなく, 低，中，高音域全体の純音聴力が相関している と結論した ${ }^{2)}$ が, 今回の検討でも純音聴力の低 音域のみあるいは中音域のみが改善しても, 語
音聴力は改善しなかった例が多く, 語音聴力検 查は低，中，高音域全ての聴力を反映している と考光られた。

今回の検討では, 鼓室形成術後の聴力変化の 判定は術後 1 力月といら短期間で行らよりも術 後 1 年目といった比較的長期を経てから行らこ とが望ましい事が示唆された。また，我々が前 回検討した 1 力月目の検討と同様に, 語音聴力 検査結果と純音聴力検査の結果とが術後 1 年目 までの推移でも一致しない場合があり, 鼓室形 成術後の聴力変化の判定には語音聴力検査と純 音聴力検査とを併せて行うことが望ましいと考 完れた。

\section{まとめ}

1 ) 術前, 術後ともに骨導聴力閾値が正常な 78 耳の鼓室形成術施行例の術前, 術後 1 力月目, 術後 1 年目の純音聴力レベルと語音聴力閾值の 結果を比較した。

2 ) 鼓室形成術後の聴力の判定の時期につい ては術後 1 力月目といら短期間で行らよりも, 術後 1 年目といった比較的長期を経てから行ら ことが望ましいと思われた。

3 ）術後, 語音聴力検査の結果と純音聴力検 査の結果とが一致しない場合があり，鼓室形成 術後の聴力変化の判定には語音聴力検査と純音 聴力検査とを併せて行らことが望をしいと考光 られた。

\section{文 献}

1）瀧本 勲, 稲福 繁, 山田一美: 鼓室形成術に 扮ける語音聴力の変動について.耳鼻臨床 69: 1057 1069, 1976.

2）小林 謙, 佐久間文子, 神尾友和, 他: 鼓室形 成術後の語音聴力検查. 耳鼻臨床 $82: 15 \sim 20$, 1989.

3）中野雄一, 本多芳男, 坂井 真, 他: 鼓室形成 術の成績判定について(提案). 臨床耳科 14 : 306 307, 1987.

4）八木聰明, 青木秀治, 馬場俊吉, 他 : 鼓室形成 術の術後観察について.耳鼻臨床 $79: 1249$ 1253, 1986 .

5）瀧本 勲: 術後成績判定上の問題点 一とくに 
聴力成績をめぐって一. 耳鼻臨床 $80: 1023$ 1029, 1987.

6）鈴木淳一：鼓室形成術 一I 型から 0 型まで一. 88 92頁, 医学書院, 東京, 1982.

(原稿受付: 平成 2 年10月 1 日 原稿採択 : 平成 2 年 12 月 17 日

別刷請求先 : 相原康孝

干101 東京都干代田区神田淡路町2-25
神尾記念病院耳鼻咽喉科 